\section{A Rapid, Simple Method for Detecting PCR Failure}

\author{
Mark J. Pallen, \\ Loretto H. Puckey, and \\ Brendan W. Wren
}

Department of Medical Microbiology,

St. Bartholomew's Hospital Medical College, London, EC1A 7BE, UK
The polymerase chain reaction (PCR) holds great potential for the rapid and sensitive detection of pathogenic microorganisms. ${ }^{(1)}$ There has been much interest in detecting and preventing falsepositive PCR results owing to product carry-over $^{(2)}$; however, less attention has been paid to false-negative reactions. These can result from defective PCR reagents, mistakes in setting up the PCR, or from inhibitory substances present in the sample. To distinguish true negative reactions from failed PCRs, we have devised a simple method in which an additional artificial template is incorporated into the amplification mixture. This template is constructed by engineering a small deletion in the usual PCR product. The control template is amplified by the same primers as the test fragment, but can be distinguished from it by mobility on electrophoresis. Using such an approach, there are three possible outcomes to a PCR: (1) no DNA is amplified in the PCR (the assay has failed); (2) the control, but not the test, fragment is obtained (the assay has worked, and the sample is negative); (3) the test fragment, with or without the control fragment, is obtained (the assay has worked, and the sample is positive).

We have applied this technique to two different PCR assays-one for the detection of toxigenic Corynebacterium diphtheriae), ${ }^{(3)}$ the other for the identification of pathogenic yersinias. ${ }^{(4)} \mathrm{We}$ constructed the control template in both cases by creating a deletion in the central portion of the natural PCR product (see Fig. 1).

\section{METHODS}

\section{Assay for Toxigenic C. diphtheriae}

Three $100-\mu l$ reactions were set up, using a boiled-cell preparation from a toxigenic strain of $C$. diphtheriae as template. Amplification conditions have been described elsewhere. ${ }^{(3)}$ After amplification, the PCR product was digested with $R s a$ I for $2 \mathrm{hr}$ in the amplification buffer at $37^{\circ} \mathrm{C}$. The digests were pooled, ethanolprecipitated, and electrophoresed on a $3 \%$ agarose gel. The two fragments (128 and $65 \mathrm{bp}$ ) flanking the central portion (42 bp) were gel-purified, ethanol-precipitated together, then ligated overnight in a $20-\mu l$ volume. PCR was repeated under the same conditions as above, using $5 \mu$ l of the ligation mix as template. Although the 65-bp fragment

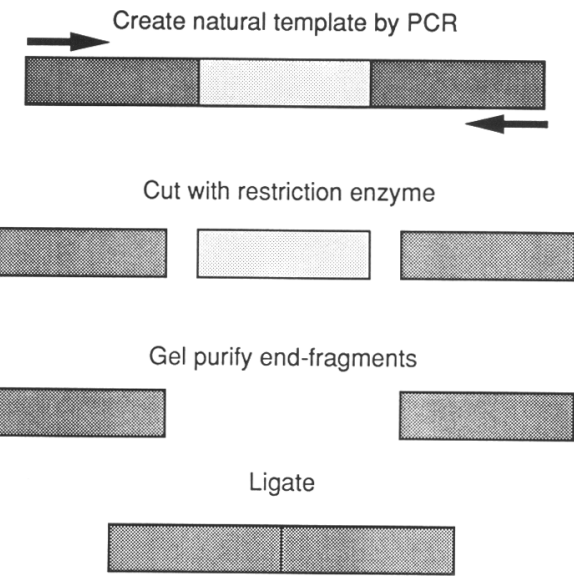

Create limitless amounts of control template by PCR

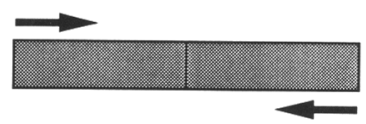

Dilute and add as control to PCRs

FIGURE 1 Strategy for constructing control template.

contained only 15 bp of the 29-bp upstream primer sequence ( 14 bp was lost in the Rsal digestion) this did not prevent amplification. A DNA fragment 42 bp smaller than the normal template was obtained. The truncated primer-binding site was reconstituted in this PCR, so that in all subsequent amplifications, the primer-binding sites of the control fragment were identical to those in the natural template. Two rounds of gel purification and repeated amplification of the fragment were then carried out. The final PCR was diluted in water in a series of three 1000 -fold dilutions. One microliter of each of these dilutions was used as template in $100-\mu 1$ reactions, under the same conditions as before. The PCR with the $10^{6}$-fold dilution gave a product of approximately equal intensity to the fragment of the diphtheria toxin gene amplified in a conventional PCR, and so this dilution was used in future studies. In a pilot study, $1 \mu \mathrm{l}$ of a $10^{6}$-fold dilution of the amplified fragment was used as control template in an assay of six toxigenic and five nontoxigenic strains of $C$. diphtheriae (see Fig. 2).

\section{Assay for Pathogenic Yersinias}

A similar approach was applied to the construction of a control template for a PCR assay for the identification of pathogenic yersinias. In this case, the natural 


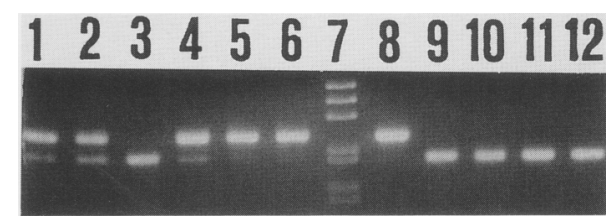

FIGURE 2 PCR assay of six toxigenic strains (lanes 1, 2, 4, 5, 6, and 8) and five nontoxigenic strains (lanes $3,9,10,11$, and 12) of $C$. diphtheriae, showing control PCR products (206 bp) and/or test products ( $248 \mathrm{bp}$ ). Lane 7 contains molecular weight markers (1 kb ladder, GIBCO BRL, Paisley, UK).

591-bp PCR product was digested with Hinfl, to give end-fragments of $114 \mathrm{bp}$ and $350 \mathrm{bp}$, with an internal fragment of $127 \mathrm{bp}$. The two end fragments were ligated together to produce a 464-bp control template. This control fragment was then incorporated in an assay of five pathogenic and three nonpathogenic strains of Yersinia (see Fig. 3).

\section{RESULTS AND DISCUSSION}

In both studies, the control fragment was clearly amplified in all the negative reactions. Although, in general, smaller fragments are amplified more efficiently than larger ones, the presence of the control fragment did not interfere with the amplification of the larger natural PCR product in the positive reactions. Indeed, in some of the positive reactions in the $C$. diphtheriae assay, the conventional template appears to have been synthesized in preference to the control. Why this happens is not clear-the artificial template may be at a disadvantage compared to the natural template be-

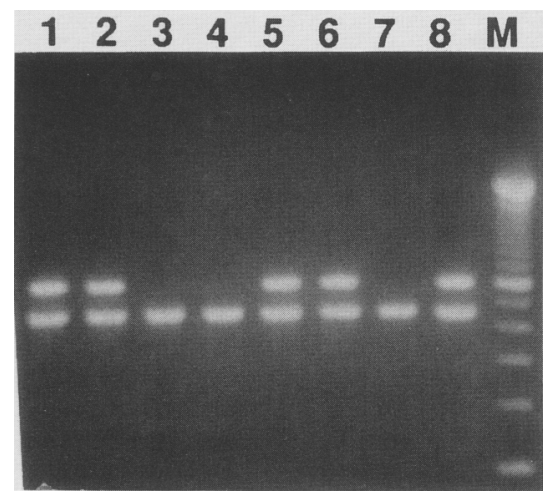

FIGURE 3 PCR assay of five pathogenic strains (lanes 1, 2, 5, 6, and 8) and three nonpathogenic strains of Yersinia, showing control PCR products (464 bp) and/or test products (591 bp). Lane $M$ contains molecular weight markers (100-bp ladder, GIBCO BRL, Paisley, UK). cause it has ragged ends produced during its synthesis by PCR, or, alternatively, partially synthesized strands from the control DNA might anneal to the longer strands of the natural template and then be extended, causing the smaller fragment to be "incorporated" into the larger one.

Another phenomenon, which one might anticipate, but which has not been observed empirically, is the formation of heteroduplexes between the natural and control templates. Presumably, even at the end of the PCR, the DNA strands still bind preferentially to the primers, which are then extended in the final 10-min extension step, rather than to the other DNA strands.

This approach to controlling PCRs has been shown to be robust; since the initial study, the internal control has been used in over 200 PCR assays for the diphtheria toxin gene (data not shown). It has proven invaluable in distinguishing between negative results due to failed reactions and negative results from isolates that lack the diphtheria toxin gene. The fact that this approach also worked with the PCR assay for pathogenic yersinias suggests that it should be generally applicable to any PCR assay in which the amplification product contains two or more compatible restriction sites.

\section{ACKNOWLEDGMENTS}

We thank G. Coleman, B. Cookson, and A. Efstratiou for strains. This work was supported by the British Society for the Study of Infection.

\section{REFERENCES}

1. Palen, M. and P. Butcher. 1991. New strategies in microbiological diagnosis. $J$. Hosp. Infect. (suppl. A) 18: 147-158.

2. Kwok, S. and R. Higuchi. 1989. Avoiding false positives with PCR. Nature 339: 237-238.

3. Pallen, M. 1991. Rapid screening for toxigenic Corynebacterium diphtheriae by polymerase chain reaction. J. Clin. Pathol. 44: 1025-1026.

4. Wren, B.W. and S. Tabaqchali. 1990. Detection of pathogenic Yersinia enterocolitica by the polymerase chain reaction. Lancet 336: 693.

Received August 7, 1991; accepted in revised form April 1, 1992. 


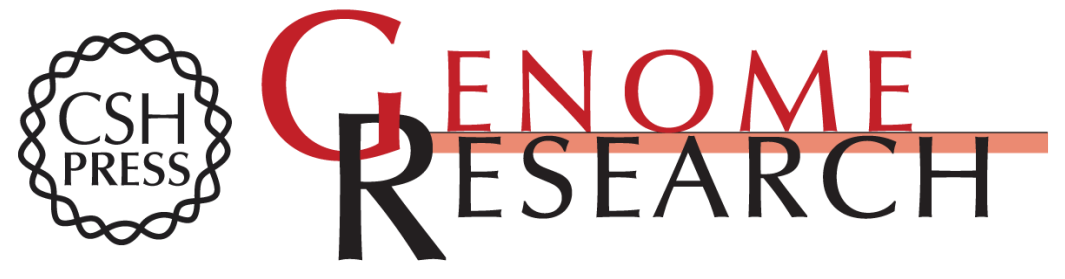

\section{A rapid, simple method for detecting PCR failure.}

M J Pallen, L H Puckey and B W Wren

Genome Res. 1992 2: 91-92

Access the most recent version at doi:10.1101/gr.2.1.91

References This article cites 4 articles, 1 of which can be accessed free at:

http://genome.cshlp.org/content/2/1/91.full.html\#ref-list-1

License

Email Alerting Receive free email alerts when new articles cite this article - sign up in the box at the Service top right corner of the article or click here.

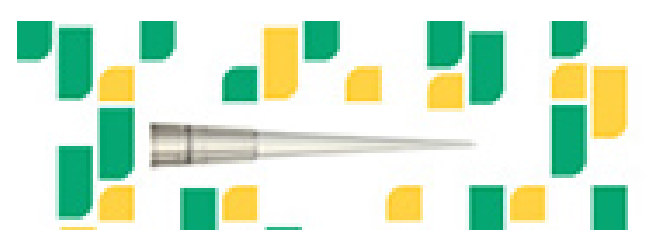

To subscribe to Genome Research go to: https://genome.cshlp.org/subscriptions 